\title{
Minimum volume standards in German hospitals: do they get along with procedure centralization? A retrospective longitudinal data analysis
}

\author{
Werner de Cruppé, Marc Malik and Max Geraedts
}

\begin{abstract}
Background: Compliance with minimum volume standards for specific procedures serves as a criterion for high-quality patient care. International experiences report a centralization of the respective procedures. In Germany, minimum volume standards for hospitals were introduced in 2004 for 5 procedures (complex esophageal and pancreatic interventions; liver, kidney and stem cell transplantations), in 2006 total knee replacement was added. This study explores whether any centralization is discernible for these procedures in Germany.

Methods: A retrospective longitudinal analysis of secondary data serves to determine a possible centralization of procedures from the system perspective. Centralization means that over time, fewer hospitals perform the respective procedure, the case volume in high-volume hospitals increases together with their percentage of the annual total case volume, and the case volume in low-volume hospitals decreases together with their percentage of the annual total case volume. Using data from the mandatory hospital quality reports for the years 2006, 2008 and 2010 we performed Kruskal Wallis and chi-square tests to evaluate potential centralization effects.
\end{abstract}

Results: No centralization was found for any of the six types of interventions over the period from 2006 to 2010. The annual case volume and the number of hospitals performing interventions rose at differing rates over the 5 -year period depending on the type of intervention. Seven percent of esophagectomies and $14 \%$ of pancreatectomies are still performed in hospitals with less than 10 interventions per year.

Conclusions: For the purpose of further centralization of interventions it will be necessary to first analyze and then appropriately address the reasons for non-compliance from the hospital and patient perspective.

Keywords: Volume-outcome, Minimum volume standards, Centralization, Hospital, Germany, Pancreatectomy, Esophagectomy, Transplantation, Arthroplasty, Replacement, Knee

\section{Background}

Minimum volumes are still deemed to be a criterion for better quality in patient care for numerous surgical interventions, since many studies and systematic reviews document better outcomes in high-volume hospitals compared to low-volume hospitals [1-16]. A shift of cases from lowvolume hospitals to high-volume hospitals is a conclusion of most studies, and in one review is even quantified as number needed to treat [17]. The volume outcome relationship and the centralization of these procedures are

\footnotetext{
*Correspondence: Werner.deCruppe@uni-wh.de

Institute for Health Systems Research, School of Medicine, Faculty of Health,

Witten/Herdecke University, Alfred-Herrhausen-Strasse 50, 58448 Witten, Germany
}

therefore two sides of the same coin. In the United States, recommendations of the National Cancer Policy Board of the Institute of Medicine [18] or initiatives such as Leapfrog on Evidence-based Hospital Referral [19] promote centralization towards high-volume hospitals. Numerous studies also assess this incipient centralization as a result of findings concerning the volume outcome relationship. For numerous types of interventions they describe a notable centralization process in US-American health care over a period of several years [20-25]. In other countries the findings on the volume outcome relationship have fed back into the development of medical care towards centralized and 
specialized care structures. The effects of such planned centralization strategies are the object of studies on health systems mainly in Europe and Japan [26-36]. These studies confirm without exception the positive correlation between high case volume and better treatment results. Nevertheless there is still some controversial debate on the pros and cons of centralization for specific interventions [37, 38]. Effects of prevalent centralization on patients are also a topic for research, with a focus on longer travel time for most and possible impairment of social support [22, 39-43].

Mandatory minimum volumes for certain defined surgical procedures were introduced in Germany in 2004 on a federal level. To date there are no studies into the implications of a possible centralization of care for these interventions. The minimum volume standards on the federal level that are mandatory for all approximately 2000 German acute-care hospitals apply to 6 types of surgical procedures, (1) complex esophageal interventions, (2) complex pancreatic interventions, (3) total knee replacement (TKR), and transplantations of (4) kidney, (5) liver and (6) stem cells. Between 2004 and 2006 these standards were raised in part and since then have remained the same (Table 1). Pertinent key figures for surgeries and procedures for each intervention are exactly defined in minimum volume regulations [44]. In Germany the Federal Joint Committee decides on minimum volume regulations. Represented in this body are the major actors of the health system, health insurance funds, physicians and hospitals; they form the joint selfgovernment of the German health care system. Minimum volume regulations do not imply any scheduled structural revision of patient care with regard to the specific interventions, such as a systematic formation of centers and centralization. If hospitals perform minimum volume procedures they are obliged to register the case numbers in their quality reports as the only format to document compliance with minimum volume regulations.

Quality reports are standardized nationwide, and all hospitals are legally required to publish their quality reports following the regulations on nature, scope and data format as defined by the Federal Joint Committee [45]. The quality report of each hospital in each reporting year consists of two data sets. One data set comprises structural and process data of the hospital, which are to be reported by the individual hospital following the regulations. These reported data are completely selfreported. A second data set for each hospital provides data on quality indicators as reported by each hospital to the official federal external quality assurance institution. These quality indicator data are validated in a structured manner including different statistical checks and a random sample of hospitals where data are verified during an on-site inspection each year. The data on minimum volume standards belong to the first data set without an external validation procedure. Hospital reports are publicly available on the Internet. An electronic data set of each reporting year can be obtained on application from the Federal Joint Committee. Reports on every second year of operation were mandatory from 2004 to 2012, and annual mandatory reports were introduced in 2013. Hospital quality reports for 2012 have been published in the summer of 2014.

In a preliminary evaluation of the consequences of the introduction of minimum volumes in German hospitals the authors reported earlier how many German hospitals performed the 5 procedures stipulated for 2004, how many complied with minimum volume standards, and indicated possible implications for geographically equal access to health care if all non-complying hospitals were excluded [46-49]. In 2014 the authors published a study updating the results on the research question how many hospitals complied with the minimum volume standards

Table 1 Specifications as per minimum volume regulations 2004 to 2012 for German hospitals: minimum volumes per hospital and year

\begin{tabular}{|c|c|c|c|c|c|}
\hline Type of intervention (including) & 2004 & 2006 & 2008 & 2010 & 2012 \\
\hline $\begin{array}{l}\text { Complex esophageal interventions (partial/total } \\
\text { esophagectomy, implant of magnetic antireflux device, } \\
\text { gastrectomy with subtotal esophageal resection) }\end{array}$ & 5 & 10 & 10 & 10 & 10 \\
\hline $\begin{array}{l}\text { Complex pancreatic interventions (partial/total } \\
\text { pancreatectomy, internal drainage of pancreas) }\end{array}$ & 5 & 10 & 10 & 10 & 10 \\
\hline Kidney transplantation (re-transplantation) & 20 & 25 & 25 & 25 & 25 \\
\hline $\begin{array}{l}\text { Liver transplantation (re-transplantation, hepatectomy, } \\
\text { partial hepatectomy from living donor) }\end{array}$ & 10 & 20 & 20 & 20 & 20 \\
\hline $\begin{array}{l}\text { Stem cell transplantation (transplantation of } \\
\text { hematopoietic stem cells from bone marrow, } \\
\text { transfusion of peripheral hematopoietic stem cells) }\end{array}$ & 12 & 25 & 25 & 25 & 25 \\
\hline Total knee replacement & - & 50 & 50 & 50 & 50 \\
\hline
\end{tabular}


in each of the until then available hospital quality report data sets for the years 2004, 2006, 2008 and 2010 [50]. They could show that the number of hospitals not meeting the standard did not change over the years under study. The present study, however, does not focus on the number of hospitals not complying versus those complying with the standards but investigates the research question if from a health care system's perspective a centralization occured over the time period from 2006 to 2010 with constant minimum volume standards (Table 1 ).

\section{Methods}

The retrospective longitudinal analysis of secondary data is based on mandatory hospital quality reports for the years 2006, 2008 and 2010. Minimum volume data reported by hospitals are compared separately for the 6 types of interventions in the three years under review.

Centralization is operationalized for the purpose of this study as change over time in three respects: (1) the number of hospitals performing the respective procedure decreases over time; (2) the volume, i.e. number of cases, in high-volume hospitals and their percentage in the annual entire volume increase over time; (3) the volume in low-volume hospitals and their percentage in the annual entire volume decrease over time.

Hospital data on minimum volume procedures were exported from quality reports to EXCEL files for each year under review, whereby the number of performing hospitals and cases were descriptively registered for each minimum volume procedure and each year under review. For a comparison of annual volumes the hospitals were divided in quintiles (esophagus, pancreas, total knee replacement), and into tertiles for the three transplantation procedures. Hospitals were ranked according to number of performed procedures per type of intervention and year, and divided into exact quintile and tertile groups. A possible change in case distribution due to changing annual volumes and in the number of performing hospitals was taken into account in the formation of quintile and tertile groups by individual new rankings of groups for the years 2006, 2008 and 2010 respectively.

Volumes of quintile and tertile groups were analyzed statistically for significant changes within each quintile and tertile over the three years under review (intra quartile / intra tertile differences). Subsequently the relative percentage ratios between quintiles / tertiles of one year were analyzed over the three one-year periods (inter quartile / inter tertile differences). The intra quartile / intra tertile volume change over the three years was submitted to test-statistical analysis using the Kruskal Wallis test for independent, non-parametric testing of samples, since the ranked quintile and tertile groups were assumed to be not normally distributed. Test-statistical analysis of inter quartile/inter tertile differences in case numbers over the three years under review was checked with a chi-square test for each minimum volume. The statistics software IBM SPSS Statistics Version 21 was used for test-statistical analysis.

\section{Ethics statement}

The authors declare that their study does not need ethical approval. All data used in this study are publicly available and usable due to legal obligations of hospitals to provide a high standard of transparency and offer information for patients, hospitals, health insurers, research and politics. Single hospital quality reports can be accessed via: http://www.g-ba-qualitaetsberichte.de/. Electronic data sets (XML format) of the quality reports can be requested from the Federal Joint Committee via: https://www.g-ba.de/institution/themenschwerpunkte/ qualitaetssicherung/qualitaetsbericht/xml-daten/.

\section{Results}

Number of hospitals per minimum volume and compliance with minimum volume standards over time

The basic data on the number of hospitals and cases per year and minimum volume are listed in Tables 2 to 7 in the upper part respectively. From 2006 to 2010, the number of hospitals performing pancreatic, esophageal and total knee replacement interventions increased by 4 to $11 \%$, and the annual volume increased by 8 to $25 \%$. For all three minimum volumes the number of hospitals complying with the minimum volume standards remained constant or increased slightly. A major difference is notable in the percentage of complying hospitals between pancreatic interventions (70\%), esophageal interventions (55\%) and total knee replacement (90\%). For the volume, the percentage of cases in hospitals meeting minimum volume standards is between 85 and $99 \%$. The number of hospitals for stem cell and liver transplantations is constant over time, whereas a slight decrease has been registered for kidney transplantations. The percentage of hospitals complying with minimum volume standards is over $90 \%$ for kidney and liver transplantations, but for stem cell transplantations is $75 \%$ with a downward trend. For the cases treated in these hospitals the percentage is over $95 \%$ respectively.

\section{Caseload change over time}

Tables 2, 3, 4, 5, 6 and 7 present results for caseload changes in each quintile/tertile over the three years under review. For pancreatic interventions (Table 2), the caseloads increased significantly over time from the 2nd quintile (hospital group with the second most frequent volumes) up to the 4th quintile (hospital group with second-lowest volume); in the 1st quintile (hospital group with most frequent volume) the percentage of 
Table 2 Number of hospitals and cases for complex pancreatic interventions in 2006, 2008, and 2010 and number of cases per quintile

\begin{tabular}{|c|c|c|c|c|}
\hline & 2006 & 2008 & 2010 & $\mathrm{p}$ \\
\hline Hospitals with no. of cases $\geq 1$ & 437 & 444 & 461 & \\
\hline Change to 2006 & - & $+1,6 \%$ & $+5,5 \%$ & \\
\hline Annual no. of cases & 8258 & 8843 & 9180 & \\
\hline Change to 2006 & - & $+7,1 \%$ & $+11,2 \%$ & \\
\hline Min. - max. & $1-384$ & $1-395$ & $1-427$ & \\
\hline Median & 11,00 & 13,00 & 13,00 & \\
\hline Mean (SD) & $18,90(31,6)$ & $19,92(29,3)$ & $19,91(29,6)$ & \\
\hline $\begin{array}{l}\text { Hospitals complying MVS*: } \\
10 \text { per year }\end{array}$ & $279(63,8 \%)$ & $311(70,0 \%)$ & $328(71,1 \%)$ & \\
\hline No. of cases in hospitals complying MVS & $7534(91,2 \%)$ & $8236(93,1 \%)$ & $8576(93,4 \%)$ & \\
\hline Hospitals not complying MVS & $158(36,2 \%)$ & $133(30,0 \%)$ & $133(28,9 \%)$ & \\
\hline $\begin{array}{l}\text { No. of cases in hospitals not } \\
\text { complying MVS }\end{array}$ & $724(8,8 \%)$ & $607(6,9 \%)$ & $604(6,6 \%)$ & \\
\hline Quintile 1 hospitals & 87 & 88 & 92 & \\
\hline No. of cases & 4794 & 4938 & 5087 & $0,735^{* *}$ \\
\hline Percentage of annual cases & $58,0 \%$ & $55,8 \%$ & $55,4 \%$ & \\
\hline Min. - max. & $25-384$ & $25-395$ & $27-427$ & \\
\hline Median & 38,00 & 40,00 & 39,00 & \\
\hline Mean (SD) & $55,10(57,0)$ & $56,11(50,6)$ & $55,29(51,8)$ & \\
\hline Quintile 2 hospitals & 87 & 89 & 92 & \\
\hline No. of cases & 1550 & 1682 & 1770 & $0,002^{* *}$ \\
\hline Percentage of annual cases & $18,8 \%$ & $19,0 \%$ & $19,3 \%$ & \\
\hline Min. - max. & $14-25$ & $15-25$ & $15-26$ & \\
\hline Median & 17,00 & 18,00 & 18,00 & \\
\hline Mean (SD) & $17,82(3,4)$ & $18,90(2,5)$ & $19,24(3,2)$ & \\
\hline Quintile 3 hospitals & 87 & 89 & 92 & \\
\hline No. of cases & 1010 & 1152 & 1182 & $<0,001^{* *}$ \\
\hline Percentage of annual cases & $12,2 \%$ & $13,0 \%$ & $12,9 \%$ & \\
\hline Min. - max. & $10-14$ & $11-15$ & $11-15$ & \\
\hline Median & 12,00 & 13,00 & 13,00 & \\
\hline Mean (SD) & $11,61(1,1)$ & $12,94(1,3)$ & $12,85(1,3)$ & \\
\hline Quintile 4 hospitals & 88 & 89 & 92 & \\
\hline No. of cases & 673 & 802 & 860 & $<0,001^{* *}$ \\
\hline Percentage of annual cases & $8,1 \%$ & $9,1 \%$ & $9,4 \%$ & \\
\hline Min. - max. & $5-10$ & $6-11$ & $7-11$ & \\
\hline Median & 8,00 & 10,00 & 10,00 & \\
\hline Mean (SD) & $7,65(1,6)$ & $9,01(1,5)$ & $9,35(1,3)$ & \\
\hline Quintile 5 hospitals & 88 & 89 & 93 & \\
\hline No. of cases & 231 & 269 & 281 & $0,295^{* *}$ \\
\hline Percentage of annual cases & $2,8 \%$ & $3,0 \%$ & $3,1 \%$ & 0,999\# \\
\hline Min. - max. & $1-5$ & $1-6$ & $1-6$ & \\
\hline Median & 3,00 & 3,00 & 3,00 & \\
\hline Mean (SD) & $2,63(1,4)$ & $3,02(1,8)$ & $3,02(1,7)$ & \\
\hline
\end{tabular}

*minimum volume standards; **Kruskal-Wallis-test; \# chi-square-test 
Table 3 Number of hospitals and cases for complex esophageal interventions in 2006, 2008, and 2010 and number of cases per quintile

\begin{tabular}{|c|c|c|c|c|}
\hline & 2006 & 2008 & 2010 & $\mathrm{p}$ \\
\hline Hospitals with no. of cases $\geq 1$ & 271 & 275 & 283 & \\
\hline Change to 2006 & - & $+1,5 \%$ & $+4,4 \%$ & \\
\hline Annual no. of cases & 3315 & 3422 & 3576 & \\
\hline Change to 2006 & - & $+3,2 \%$ & $+7,9 \%$ & \\
\hline Min. - max. & $1-150$ & $1-124$ & $1-112$ & \\
\hline Median & 10,00 & 10,00 & 10,00 & \\
\hline Mean (SD) & $12,23(13,8)$ & $12,44(14,1)$ & $12,64(14,2)$ & \\
\hline Hospitals complying MVS*: 10 per year & $154(56,8 \%)$ & $148(53,8 \%)$ & $160(56,5 \%)$ & \\
\hline $\begin{array}{l}\text { No. of cases in hospitals } \\
\text { complying MVS }\end{array}$ & $2809(84,7 \%)$ & $2875(84,0 \%)$ & $3066(85,7 \%)$ & \\
\hline Hospitals not complying MVS & $117(43,2 \%)$ & $127(46,2 \%)$ & $123(43,5 \%)$ & \\
\hline $\begin{array}{l}\text { No. of cases in hospitals not } \\
\text { complying MVS }\end{array}$ & $506(15,3 \%)$ & $547(16,0 \%)$ & $510(14,3 \%)$ & \\
\hline Quintile 1 hospitals & 54 & 55 & 57 & \\
\hline No. of cases & 1636 & 1800 & 1857 & $0,302^{* *}$ \\
\hline Percentage of annual cases & $49,4 \%$ & $52,6 \%$ & $51,9 \%$ & \\
\hline Min. - max. & $16-150$ & $17-124$ & $17-112$ & \\
\hline Median & 22,50 & 24,00 & 23,00 & \\
\hline Mean (SD) & $30,30(22,0)$ & $32,73(20,3)$ & $32,58(20,7)$ & \\
\hline Quintile 2 hospitals & 54 & 55 & 56 & \\
\hline No. of cases & 696 & 687 & 729 & $0,165^{* *}$ \\
\hline Percentage of annual cases & $21,0 \%$ & $20,1 \%$ & $20,4 \%$ & \\
\hline Min. - max. & $11-16$ & $11-16$ & $11-17$ & \\
\hline Median & 12,50 & 12,00 & 12,00 & \\
\hline Mean (SD) & $12,89(1,5)$ & $12,49(1,6)$ & $13,02(1,8)$ & \\
\hline Quintile 3 hospitals & 55 & 55 & 57 & \\
\hline No. of cases & 557 & 537 & 569 & $0,040^{* *}$ \\
\hline Percentage of annual cases & $16,8 \%$ & $15,7 \%$ & $15,9 \%$ & \\
\hline Min. - max. & $8-11$ & $8-11$ & $8-11$ & \\
\hline Median & 10,00 & 10,00 & 10,00 & \\
\hline Mean (SD) & $10,13(0,7)$ & $9,76(0,8)$ & $9,98(0,6)$ & \\
\hline Quintile 4 hospitals & 54 & 55 & 56 & \\
\hline No. of cases & 321 & 297 & 325 & $0,092^{* *}$ \\
\hline Percentage of annual cases & $9,7 \%$ & $8,7 \%$ & $9,1 \%$ & \\
\hline Min. - max. & $4-8$ & $4-8$ & $3-8$ & \\
\hline Median & 6,00 & 5,00 & 6,00 & \\
\hline Mean (SD) & $5,94(1,3)$ & $5,40(1,3)$ & $5,80(1,4)$ & \\
\hline Quintile 5 hospitals & 54 & 55 & 57 & \\
\hline No. of cases & 105 & 101 & 96 & $0,405^{* *}$ \\
\hline Percentage of annual cases & $3,2 \%$ & $3,0 \%$ & $2,7 \%$ & 0,999\# \\
\hline Min. - max. & $1-4$ & $1-4$ & $1-3$ & \\
\hline Median & 2,00 & 2,00 & 2,00 & \\
\hline Mean (SD) & $1,94(0,9)$ & $1,84(1,0)$ & $1,68(0,8)$ & \\
\hline
\end{tabular}

*minimum volume standards; **Kruskal-Wallis-test; \# chi-square-test 
Table 4 Number of hospitals and cases for total knee replacement interventions in 2006, 2008, and 2010 and number of cases per quintile

\begin{tabular}{|c|c|c|c|c|}
\hline & 2006 & 2008 & 2010 & $p$ \\
\hline Hospitals with no. of cases $\geq 1$ & 855 & 905 & 949 & \\
\hline Change to 2006 & - & $+5,8 \%$ & $+11,0$ & \\
\hline Annual no. of cases & 114852 & 139287 & 143593 & \\
\hline Change to 2006 & - & $+21,3 \%$ & $+25 \%$ & \\
\hline Min. - max. & $1-979$ & $1-1329$ & $1-1367$ & \\
\hline Median & 93,00 & 109,00 & 107,00 & \\
\hline Mean (SD) & $134,33(126,7)$ & $153,91(144,1)$ & $151,31(140,4)$ & \\
\hline $\begin{array}{l}\text { Hospitals complying MVS: } \\
50 \text { per year }\end{array}$ & $745(87,1 \%)$ & $834(92,2 \%)$ & $870(91,7 \%)$ & \\
\hline No. of cases in hospitals complying MVS & $112305(97,8 \%)$ & $137586(98,8 \%)$ & $141597(98,6 \%)$ & \\
\hline Hospitals not complying MVS & $110(12,9 \%)$ & $71(7,8 \%)$ & $79(8,3 \%)$ & \\
\hline $\begin{array}{l}\text { No. of cases in hospitals not } \\
\text { complying MVS }\end{array}$ & $2547(2,2 \%)$ & $1701(1,2 \%)$ & $1996(1,4 \%)$ & \\
\hline Quintile 1 hospitals & 171 & 181 & 190 & \\
\hline No. of cases & 56617 & 67795 & 69609 & $0,001^{* *}$ \\
\hline Percentage of annual cases & $49,3 \%$ & $48,7 \%$ & $48,5 \%$ & \\
\hline Min. - max. & $191-979$ & $215-1329$ & 219-1367 & \\
\hline Median & 276,00 & 318,00 & 309,50 & \\
\hline Mean (SD) & $331,09(153,4)$ & $374,56(181,9)$ & $366,36(177,0)$ & \\
\hline Quintile 2 hospitals & 171 & 181 & 190 & \\
\hline No. of cases & 25650 & 30686 & 31322 & $<0,001^{* *}$ \\
\hline Percentage of annual cases & $22,3 \%$ & $22,0 \%$ & $21,8 \%$ & \\
\hline Min. - max. & $117-190$ & $133-215$ & $130-218$ & \\
\hline Median & 147,00 & 168,00 & 163,50 & \\
\hline Mean (SD) & $150,00(21,3)$ & $169,54(24,3)$ & $164,85(23,7)$ & \\
\hline Quintile 3 hospitals & 171 & 181 & 189 & \\
\hline No. of cases & 16051 & 19870 & 20635 & $<0,001^{* *}$ \\
\hline Percentage of annual cases & $14,0 \%$ & $14,3 \%$ & $14,4 \%$ & \\
\hline Min. - max. & $75-116$ & $89-153$ & $91-130$ & \\
\hline Median & 93,00 & 109,00 & 107,00 & \\
\hline Mean (SD) & $93,87(11,9)$ & $109,7811,5)$ & $109,18(11,7)$ & \\
\hline Quintile 4 hospitals & 171 & 181 & 190 & \\
\hline No. of cases & 10857 & 13302 & 14042 & $<0,001^{* *}$ \\
\hline Percentage of annual cases & $9,5 \%$ & $9,6 \%$ & $9,8 \%$ & \\
\hline Min. - max. & $53-75$ & $60-89$ & $59-91$ & \\
\hline Median & 63,00 & 74,00 & 73,00 & \\
\hline Mean (SD) & $63,49(6,7)$ & $73,49(8,1)$ & $73,91(9,2)$ & \\
\hline Quintile 5 hospitals & 171 & 181 & 190 & \\
\hline No. of cases & 5677 & 7634 & 7985 & $<0,001^{* *}$ \\
\hline Percentage of annual cases & $4,9 \%$ & $5,5 \%$ & $5,6 \%$ & 0,999\# \\
\hline Min. - max. & $1-53$ & $1-60$ & $1-59$ & \\
\hline Median & 40,00 & 51,00 & 51,00 & \\
\hline Mean (SD) & $33,20(18,1)$ & $42,18(18,0)$ & $42,03(17,6)$ & \\
\hline
\end{tabular}

*minimum volume standards; **Kruskal-Wallis-test; \# chi-square-test 
Table 5 Number of hospitals and cases for kidney transplantations in 2006, 2008, and 2010 and number of cases per tercile

\begin{tabular}{|c|c|c|c|c|}
\hline & 2006 & 2008 & 2010 & $\mathrm{p}$ \\
\hline Hospitals with no. of cases $\geq 1$ & 40 & 40 & 37 & \\
\hline Change to 2006 & - & $0,0 \%$ & $-7,5 \%$ & \\
\hline Annual no. of cases & 2784 & 2784 & 2856 & \\
\hline Change to 2006 & - & $0,0 \%$ & $+2,6 \%$ & \\
\hline Min. - max. & $4-251$ & $9-255$ & $12-264$ & \\
\hline Median & 57,50 & 60,50 & 69,00 & \\
\hline Mean (SD) & $69,60(48,4)$ & $69,60(48,7)$ & $77,19(51,7)$ & \\
\hline $\begin{array}{l}\text { Hospitals complying } \\
\text { MVS*: } 25 \text { per year }\end{array}$ & 38 (95 \%) & $36(90,0 \%)$ & $35(94,6 \%)$ & \\
\hline $\begin{array}{l}\text { No. of cases in hospitals } \\
\text { complying MVS }\end{array}$ & $2769(99,5 \%)$ & $2721(97,7 \%)$ & $2824(98,9 \%)$ & \\
\hline Hospitals not complying MVS & $2(5,0 \%)$ & $4(10,0 \%)$ & $2(5,4 \%)$ & \\
\hline $\begin{array}{l}\text { No. of cases in hospitals } \\
\text { not complying MVS }\end{array}$ & $15(0,5 \%)$ & $63(2,3 \%)$ & $32(1,1 \%)$ & \\
\hline Tercile 1 hospitals & 13 & 13 & 12 & \\
\hline No. of cases & 1581 & 1597 & 1598 & $0,438^{* *}$ \\
\hline Percentage of annual cases & $56,8 \%$ & $57,3 \%$ & $56,0 \%$ & \\
\hline Min. - max. & $85-251$ & $86-255$ & $96-264$ & \\
\hline Median & 105,00 & 107,00 & 117,00 & \\
\hline Mean (SD) & $121,62(48,3)$ & $122,85(47,5)$ & $133,17(51,0)$ & \\
\hline Tercile 2 hospitals & 14 & 14 & 13 & \\
\hline No. of cases & 837 & 830 & 883 & $0,288^{* *}$ \\
\hline Percentage of annual cases & $30,1 \%$ & $29,8 \%$ & $30,9 \%$ & \\
\hline Min. - max. & $39-84$ & $39-84$ & $40-94$ & \\
\hline Median & 57,50 & 60,50 & 69,00 & \\
\hline Mean (SD) & $59,79(16,1)$ & $59,29(15,1)$ & $67,92(15,6)$ & \\
\hline Tercile 3 hospitals & 13 & 13 & 12 & \\
\hline No. of cases & 366 & 357 & 375 & $0,433^{* *}$ \\
\hline Percentage of annual cases & $13,1 \%$ & $12,8 \%$ & $13,1 \%$ & 0,999\# \\
\hline Min. - max. & $4-38$ & $9-38$ & $12-39$ & \\
\hline Median & 32,00 & 30,00 & 33,50 & \\
\hline Mean (SD) & $28,15(10,4)$ & $27,46(9,0)$ & $31,25(8,0)$ & \\
\hline
\end{tabular}

*minimum volume standards; **Kruskal-Wallis-test; \# chi-square-test

cases declined slightly and in the 5th quintile (hospital group with lowest volumes) it slightly rose. For esophageal interventions (Table 3), the caseload in each quintile did not change significantly, except for the 3rd quintile (hospital group with medium volumes) where it declined with $p=0,040$. Total knee replacement interventions (Table 4) showed a significant increase in volume over all quintiles. For all three transplantation procedures (Tables 5, 6 and 7) the volume remained constant in tertile groups over time. Statistical analysis of the relative percentage of case distribution between the three years under review over all quintiles / tertiles of each minimum volume reveals p values of over $0.99 \%$ in the chisquare test for all minimum volumes. This corresponds virtually to a constant relative volume distribution for all minimum volumes over the period under consideration.

\section{Discussion}

No centralization of care was found in the German hospital sector for the 6 minimum volume interventions from 2006 to 2010. The three criteria for centralization less hospitals perform an intervention, growing case load and higher percentage of cases in high-volume hospitals, and declining case load and lower percentage of cases in low-volume hospitals - do not apply to any of the six types of interventions. On the contrary, the percentage of hospitals performing the respective minimum volume procedures rose for four of the procedures by between 
Table 6 Number of hospitals and cases for stem cell transplantations in 2006, 2008, and 2010 and number of cases per tercile

\begin{tabular}{|c|c|c|c|c|}
\hline & 2006 & 2008 & 2010 & \\
\hline Hospitals with no. of cases $\geq 1$ & 81 & 73 & 84 & \\
\hline Change to 2006 & - & $-9,9 \%$ & $+2,5 \%$ & \\
\hline Annual no. of cases & 6181 & 5542 & 6320 & \\
\hline Change to 2006 & - & $-10,3 \%$ & $+2,2 \%$ & \\
\hline Min. - max. & $1-349$ & $1-306$ & $1-320$ & \\
\hline Median & 40,00 & 40,00 & 38,50 & \\
\hline Mean (SD) & $76,31(78,9)$ & $75,92(74,9)$ & $75,24(77,5)$ & \\
\hline Hospitals complying MVS*: 25 per year & $63(77,8 \%)$ & $55(75,3 \%)$ & $62(73,8 \%)$ & \\
\hline No. of cases in hospitals complying MVS & $5927(95,9 \%)$ & $5290(95,5 \%)$ & $6030(95,4 \%)$ & \\
\hline Hospitals not complying MVS & $18(22,2 \%)$ & $18(24,7 \%)$ & $21(26,2 \%)$ & \\
\hline No. of cases in hospitals not complying MVS & $254(4,1 \%)$ & $252(4,5 \%)$ & $290(5,6 \%)$ & \\
\hline Tercile 1 hospitals & 27 & 24 & 28 & \\
\hline No. of cases & 4497 & 3940 & 4694 & $0,904^{* *}$ \\
\hline Percentage of annual cases & $72,8 \%$ & $71,1 \%$ & $74,3 \%$ & \\
\hline Min. - max. & $80-349$ & $83-306$ & $82-320$ & \\
\hline Median & 143,00 & 153,00 & 158,00 & \\
\hline Mean (SD) & $166,56(76,1)$ & $164,17(67,1)$ & $167,64(167,6)$ & \\
\hline Tercile 2 hospitals & 27 & 24 & 28 & \\
\hline No. of cases & 1202 & 1170 & 1184 & $0,381^{* *}$ \\
\hline Percentage of annual cases & $19,4 \%$ & $21,1 \%$ & $18,7 \%$ & \\
\hline Min. - max. & $27-79$ & $27-82$ & $26-82$ & \\
\hline Median & 40,00 & 40,50 & 38,50 & \\
\hline Mean (SD) & $44,52(16,0)$ & $48,75(19,3)$ & $42,29(16,1)$ & \\
\hline Tercile 3 hospitals & 27 & 25 & 28 & \\
\hline No. of cases & 482 & 432 & 442 & $0,547^{* *}$ \\
\hline Percentage of annual cases & $7,8 \%$ & $7,8 \%$ & $7,0 \%$ & 0,990\# \\
\hline Min. - max. & $1-26$ & $1-26$ & $1-26$ & \\
\hline Median & 19,00 & 19,00 & 16,00 & \\
\hline Mean (SD) & $17,85(7,6)$ & $17,28(8,5)$ & $15,79(7,7)$ & \\
\hline
\end{tabular}

*minimum volume standards; **Kruskal-Wallis-test; \# chi-square-test

2.5 and $11 \%$ over the 5-year period, remained constant only for liver transplantations, and declined for kidney transplantations. The percentage of the annual distribution of volume percentages between the quintiles/tertiles is virtually identical for all minimum volumes over the three years under review. The increase in caseload for all 6 procedures did not affect centralization tendencies. The strong increase in case loads for pancreatic (11\%), esophageal (8\%) and total knee replacement (25\%) interventions over the 5 -year period resulted in a significant increase over all quintiles for total knee replacement, and over several of the intermediate quintiles for the two other procedures. For these three procedures the volume increase is higher than the average $7.3 \%$ increase for all in-patient admissions to German hospitals from 2006 to 2010.
What are possible reasons why no centralization occured in any of the introduced minimum volume interventions? We assume different contributing factors in each of the procedures. Liver and kidney transplantation, with 23 and 40 delivering centers nationwide respectively, were already highly centralized before introducing minimum volume standards and no further centralization was expected [46]. Stem cell transplantations are a special case in this context, since they are not subject to regulations for organ transplants as liver and kidney transplantation. Their indication is governed by dynamic developments in medicine, as may be seen from volatile figures for hospitals and case loads over the three years under study, with a tendency towards more hospitals, and cases performed without meeting minimum standards. The high reimbursements may be an additional incentive 
Table 7 Number of hospitals and cases for liver transplantations in 2006, 2008, and 2010 and number of cases per tercile

\begin{tabular}{|c|c|c|c|c|}
\hline & 2006 & 2008 & 2010 & \\
\hline Hospitals with no. of cases $\geq 1$ & 23 & 23 & 23 & \\
\hline Change to 2006 & - & $0,0 \%$ & $0,0 \%$ & \\
\hline Annual no. of cases & 1381 & 1386 & 1464 & \\
\hline Change to 2006 & - & $+0,4 \%$ & $+6,0 \%$ & \\
\hline Min. - max. & $16-143$ & $11-146$ & $17-160$ & \\
\hline Median & 51,00 & 47,00 & 60,00 & \\
\hline Mean (SD) & $60,04(36,7)$ & $60,26(37,9)$ & $63,65(35,7)$ & \\
\hline $\begin{array}{l}\text { Hospitals complying } \\
\text { MVS*: } 20 \text { per year }\end{array}$ & $22(95,7 \%)$ & $20(87,0 \%)$ & $22(95,7 \%)$ & \\
\hline $\begin{array}{l}\text { No. of cases in hospitals } \\
\text { complying MVS }\end{array}$ & 1365 (98,8 \%) & 1349 (97,3 \%) & 1447 (98,8 \%) & \\
\hline $\begin{array}{l}\text { Hospitals not complying } \\
\text { MVS }\end{array}$ & $1(4,3 \%)$ & $3(13,0 \%)$ & $1(4,3 \%)$ & \\
\hline $\begin{array}{l}\text { No. of cases in hospitals } \\
\text { not complying MVS }\end{array}$ & $16(1,2 \%)$ & $37(2,7 \%)$ & $17(1,2 \%)$ & \\
\hline Tercile 1 hospitals & 7 & 7 & 7 & \\
\hline No. of cases & 739 & 748 & 749 & $0,989^{* *}$ \\
\hline Percentage of annual cases & $53,5 \%$ & $54,0 \%$ & $51,2 \%$ & \\
\hline Min. - max. & $65-143$ & $80-146$ & $90-160$ & \\
\hline Median & 103,00 & 102,00 & 97,00 & \\
\hline Mean (SD) & $105,57(29,6)$ & $106,86(24,4)$ & $107,00(24,4)$ & \\
\hline Tercile 2 hospitals & 8 & 8 & 8 & \\
\hline No. of cases & 426 & 444 & 483 & $0,428^{* *}$ \\
\hline Percentage of annual cases & $30,8 \%$ & $32,0 \%$ & $33,0 \%$ & \\
\hline Min. - max. & $46-60$ & $42-70$ & $43-81$ & \\
\hline Median & 53,50 & 55,50 & 60,00 & \\
\hline Mean (SD) & $53,25(5,4)$ & $55,50(13,3)$ & $60,38(12,2)$ & \\
\hline Tercile 3 hospitals & 8 & 8 & 8 & \\
\hline No. of cases & 216 & 194 & 232 & $0,578^{* *}$ \\
\hline Percentage of annual cases & $15,6 \%$ & $14,0 \%$ & $15,8 \%$ & 0,990\# \\
\hline Min. - max. & $16-41$ & $11-41$ & $17-43$ & \\
\hline Median & 24,50 & 20,50 & 28,50 & \\
\hline Mean (SD) & $27,00(8,5)$ & $24,25(12,5)$ & $29,00(9,4)$ & \\
\hline
\end{tabular}

*minimum volume standards; ${ }^{* *}$ Kruskal-Wallis-test; \# chi-square-test

for performing such interventions. Total knee replacements are very frequent interventions, performed in every second German hospital, and have increased by $25 \%$ within 5 years. The currently applicable minimum volume of 50 procedures per year must be considered as low to medium, based on the systematic review by Marlow [13]. The caseloads in German hospitals not meeting minimum volume standards are - with 1 to $2 \%$ - as low as only those for centralized liver and kidney transplantations.

In contrast, pancreatic and esophageal interventions had the highest percentage of hospitals not complying with minimum volume standards in 2006 with 36 and $43 \%$ respectively, and a centralization was expected $[46,51,52]$. Our findings on these two procedures can be contrasted by international studies quoted earlier. Numerous US studies explore the introduction of minimum volumes and the centralization processes involved for these two interventions among others. Based on a nationwide inpatient sample, Learn [20] reports that $67 \%$ of pancreatectomies were performed in hospitals with less than 10 such interventions per year from 1997 to 1999; the percentage declined to $51 \%$ from 2004 to 2006, comparable to esophagectomies with an initial percentage of $69 \%$ in hospitals with less than 6 cases per year where the percentage declined to $53 \%$. For these two intervention categories Stitzenberg [39] also 
reports a shift of cases towards high-volume hospitals, based on data collected in three US states. Between 1996 and 2006 the percentage of esophagectomies performed by hospitals with 8 or less procedures per year declined from 56 to $23 \%$, and the percentage of pancreatectomies from 63 to $31 \%$ in hospitals with 14 or less procedures per year. For Washington State, Massarweh [24] describes a decline in pancreatectomies from $41 \%$ in 1994 to $24 \%$ in 2007 in hospitals with 10 or fewer procedures per year, and from 58 to $41 \%$ for esophagectomies in hospitals with 12 or fewer procedures per year. He explicitly refers to the minimum volume requirements postulated by the Leapfrog Group as a driving force. Two aspects about these data trends in the US are noteworthy in comparison to Germany. Over the (longer) periods under review of 9 to 13 years a centralization of these interventions is observable in the United States. The achieved shifts towards high-volume hospitals are, however, still nowhere near from meeting the goal of complete or even high-level centralization. In Germany the two procedures in question were already more centralized upon introduction of minimum volume standards, and in 2010 only $14 \%$ of esophagectomies and $7 \%$ of pancreatectomies were performed by hospitals with less than 10 such surgeries per year.

From the Netherlands de Wilde [31] and Wouters [32] report the successful implementation of a minimum volume of 10 pancreatectomies per year, with a decrease in performing hospitals from 48 to 30 , and an increase from 53 to $91 \%$ in patients operated upon in hospitals with 10 and more interventions. Centralization criteria have been clearly met in this case. From the south of the Netherlands Gooiker [33] and Lemmens [34] give an impressive description of an inter-hospital, coordinated centralization of esophagectomies and pancreatectomies, leading to performance in 2 instead of 9 hospitals and to double-digit volumes.

These international experiences with introducing minimum volume standards for esophagectomies and pancreatectomies can help understanding the differing development in Germany. The low percentage of esophagectomies and pancreatectomies in German hospitals with less than 10 interventions per year reflects - in international comparison - a high degree of centralization existing prior to the introduction of minimum volume standards. Linked to this is a not equally promoted compliance with minimum volume standards on the part of medical societies, national specialist institutes or initiatives such as Leapfrog with an influence on reimbursement criteria in other countries. German minimum volume regulations oblige hospitals to comply but do not specify any sanctions. A 2006 survey among affected German hospitals not complying with minimum volumes for esophagectomies and pancreatectomies, and also among national umbrella organizations of all German sickness funds revealed that non-compliance has so far been irrelevant in the annual budget negotiations [53]. Another factor with impact on centralization processes in Germany is its federal structure. The 16 federal states in Germany are independently in charge of designing and implementing the structural planning of inpatient care, and not the Federal Joint Committee that defines nationwide minimum volume standards. This might be one important factor why on the state level in North-Rhine Westphalia breast cancer treatment was successfully concentrated in breast cancer centers, thereby reducing the number of hospitals with breast cancer treatment from about 250 to 100 [54]. This approach is comparable to The Netherlands where relocation of procedures as basic step toward centralization has been successfully fostered by specifying care structures and by cooperation in regional quality associations [31-33].

However, factors such as promoting initiatives of medical societies, reimbursement strategies, sanctions, administrative directives, and regional quality associations focus primarily on a system perspective. It might be helpful to address as well the hospital perspective to achieve stricter compliance with minimum volume standards. Especially hospitals not complying with minimum volume standards should be analysed why such procedures are performed. Factors to be studied are the relevance of and options for emergency procedures, attitudes towards and possibilities of regional cooperation and last but not least the patient view, since proximity to the place of residence and therefore to social support have a high priority for which patients are willing to accept higher risks [55].

\section{Limitations}

A limitation of this study is that the validity of data used from hospital quality reports is not quantifiable. The data are unevaluated and self-reported. It has been established that the reported data have had no practical consequences in the form of sanctions to date. But the possibility cannot be ruled out that data reported specifically from hospitals not meeting minimum volumes are inaccurate. The study does not investigate the temporal, intrahospital volume progression that would be of interest for individual hospital developments in complementing the systemic perspective of centralization, nor does it consider the influence of cooperation between hospitals on volume progression in detail. From the perspective of the individual hospital, the emergence of other regional health care structures may constitute important developments after the introduction of minimum volume standards, but has not been explored for the purposes of this study. 


\section{Conclusions}

The nationwide introduction of minimum volume standards in German hospitals for 6 procedures did not result in centralization. If the aim is to achieve better compliance with minimum volume standards, reasons for non-compliance from the hospital and the patient perspective must be analyzed in greater detail and addressed accordingly.

\section{Competing interests}

The authors declare that they have no competing interests.

\section{Authors' contributions}

WDC: He made substantial contributions to conception and design, acquisition, analysis and interpretation of data, he drafted the manuscript. MM: He made substantial contributions to data preparation, extraction, and analyses, and has been involved in drafting the manuscript. MG: He made substantial contributions to conception and design, interpretation of data, and has been involved in drafting the manuscript. All authors read and approved the final manuscript.

\section{Acknowledgements}

We thank our collegue Christina Wagner from our Communication Service at Witten/Herdecke University for her linguistic support in preparing the English language manuscript. This study received no funding.

Received: 24 March 2014 Accepted: 7 July 2015

Published online: 22 July 2015

\section{References}

1. Pieper D, Mathes T, Neugebauer E, Eikermann M. State of evidence on the relationship between high-volume hospitals and outcomes in surgery: A systematic review of systematic reviews. J Am Coll Surg. 2013:216:1015-1025.e18

2. Birkmeyer JD, Siewers AE, Finlayson EVA, Stukel TA, Lucas FL, Batista I, et al. Hospital volume and surgical mortality in the United States. N Engl J Med. 2002;346:1128-37.

3. Birkmeyer JD, Sun Y, Wong SL, Stukel TA. Hospital volume and late survival after cancer surgery. Ann Surg. 2007;245:777-83.

4. Fareed N. Size matters: a meta-analysis on the impact of hospital size on patient mortality. Int J Evid Based Healthc. 2012;10:103-11.

5. Dimick JB, Birkmeyer Jr JD, Upchurch Jr GR. Measuring surgical quality: What's the role of provider volume? World J Surg. 2005:29:1217-21.

6. Chowdhury MM, Dagash H, Pierro A. A systematic review of the impact of volume of surgery and specialization on patient outcome. Br J Surg. 2007:94:145-61.

7. Gooiker GA, van Gijn W, Post PN, van de Velde CJH, Tollenaar RAEM, Wouters MWJM. A systematic review and meta-analysis of the volume-outcome relationship in the surgical treatment of breast cancer. Are breast cancer patients better of with a high volume provider? Eur J Surg Oncol. 2010;36:S27-35.

8. Gooiker GA, van Gijn W, Wouters MWJM, Post PN, van de Velde CJH, Tollenaar RAEM, et al. Systematic review and meta-analysis of the volume-outcome relationship in pancreatic surgery. Br J Surg. 2011;98:485-94.

9. Goossens-Laan CA, Gooiker GA, van Gijn W, Post PN, Bosch JLHR, Kil PJM, et al. A systematic review and meta-analysis of the relationship between hospital/surgeon volume and outcome for radical cystectomy: an update for the ongoing debate. Eur Urol. 2011;59:775-83.

10. Gruen RL, Pitt V, Green S, Parkhill A, Campbell D, Jolley D. The effect of provider case volume on cancer mortality: systematic review and meta-analysis. CA Cancer J Clin. 2009;59:192-211.

11. Karthikesalingam A, Hinchliffe RJ, Loftus IM, Thompson MM, Holt PJ. Volume-outcome relationships in vascular surgery: the current status. J Endovasc Ther. 2010;17:356-65.

12. Markar SR, Karthikesalingam A, Thrumurthy S, Low DE. Volume-outcome relationship in surgery for esophageal malignancy: systematic review and meta-analysis 2000-2011. J Gastrointest Surg. 2012;16:1055-63.
13. Marlow NE, Barraclough B, Collier NA, Dickinson IC, Fawcett J, Graham JC, et al. Centralization and the relationship between volume and outcome in knee arthroplasty procedures. ANZ J Surg. 2010;80:234-41.

14. Sund R. Modeling the volume-effectiveness relationship in the case of hip fracture treatment in Finland. BMC Health Serv Res. 2010;10:238.

15. Woo YL, Kyrgiou M, Bryant A, Everett T, Dickinson HO. Centralisation of services for gynaecological cancer. Cochrane Database Syst Rev. 2012;3:CD007945.

16. Tol JAMG, van Gulik TM, Busch ORC, Gouma DJ. Centralization of highly complex low-volume procedures in upper gastrointestinal surgery. A summary of systematic reviews and meta-analyses. Dig Surg. 2012;29:374-83.

17. Ravi P, Bianchi M, Hansen J, Trinh Q-D, Tian Z, Meskawi M, et al. Benefit in regionalisation of care for patients treated with radical cystectomy: a nationwide inpatient sample analysis. BJU Int. 2013;113(5):733-40.

18. Hewitt M, Simone JV, editors. Ensuring quality cancer care. Washington, DC: National Academy Press; 1999.

19. The Leapfrog Group. Evidence-based hospital referral fact sheet. http://www.leapfroggroup.org/for_hospitals/leapfrog_safety_practices/ evidence-based_hospital_referral.

20. Learn PA, Bach PB. A decade of mortality reductions in major oncologic surgery: the impact of centralization and quality improvement. Med Care. 2010;48:1041-9.

21. Smaldone MC, Simhan J, Kutikov A, Canter DJ, Starkey R, Zhu F, et al. Trends in regionalization of radical cystectomy in three large northeastern states from 1996 to 2009. Urol Oncol. 2013;31:1663-9.

22. Simhan J, Smaldone MC, Canter DJ, Zhu F, Starkey R, Stitzenberg KB, et al. Trends in regionalization of adrenalectomy to higher volume surgical centers. J Urol. 2012;188:377-82.

23. Rosales-Velderrain A, Bowers SP, Goldberg RF, Clarke TM, Buchanan MA, Stauffer JA, et al. National trends in resection of the distal pancreas. World J Gastroenterol. 2012;18:4342-9.

24. Massarweh NN, Flum DR, Symons RG, Varghese TK, Pellegrini CA. A critical evaluation of the impact of Leapfrog's evidence-based hospital referral. J Am Coll Surg. 2011;212:150-159.e1.

25. Finks JF, Osborne NH, Birkmeyer JD. Trends in hospital volume and operative mortality for high-risk surgery. N Engl J Med. 2011;364:2128-37.

26. Mayer EK, Bottle A, Darzi AW, Athanasiou T, Vale JA. The volume-mortality relation for radical cystectomy in England: retrospective analysis of hospital episode statistics. BMJ. 2010;340:c1128.

27. Skipworth RJE, Parks RW, Stephens NA, Graham C, Brewster DH, Garden OJ, et al. The relationship between hospital volume and post-operative mortality rates for upper gastrointestinal cancer resections: Scotland 1982-2003. Eur J Surg Oncol. 2010;36:141-7.

28. Crawford R, Greenberg D. Improvements in survival of gynaecological cancer in the Anglia region of England: are these an effect of centralisation of care and use of multidisciplinary management? BJOG. 2012;119:160-5.

29. Forshaw MJ, Gossage JA, Stephens J, Strauss D, Botha AJ, Atkinson S, et al. Centralisation of oesophagogastric cancer services: can specialist units deliver? Ann R Coll Surg Engl. 2006;88:566-70.

30. Pal N, Axisa B, Yusof S, Newcombe RG, Wemyss-Holden S, Rhodes M, et al. Volume and outcome for major upper Gl surgery in England. J Gastrointest Surg. 2008;12:353-7.

31. De Wilde RF, Besselink MGH, van der Tweel I, de Hingh IHJT, van Eijck CHJ, Dejong $\mathrm{CHC}$, et al. Impact of nationwide centralization of pancreaticoduodenectomy on hospital mortality. Br J Surg. 2012;99:404-10

32. Wouters MWJM, Krijnen P, Le Cessie S, Gooiker GA, Guicherit OR, Marinelli AWKS, et al. Volume- or outcome-based referral to improve quality of care for esophageal cancer surgery in The Netherlands. J Surg Oncol. 2009;99:481-7.

33. Gooiker GA, van der Geest LGM, Wouters MWJM, Vonk M, Karsten TM, Tollenaar RAEM, et al. Quality improvement of pancreatic surgery by centralization in the western part of the Netherlands. Ann Surg Oncol. 2011;18:1821-9.

34. Lemmens VEPP, Bosscha K, van der Schelling G, Brenninkmeijer S, Coebergh JWW, de Hingh IHJT. Improving outcome for patients with pancreatic cancer through centralization. Br J Surg. 2011;98:1455-62.

35. Nobilio L, Fortuna D, Vizioli M, Berti E, Guastaroba P, Taroni F, et al. Impact of regionalisation of cardiac surgery in Emilia-Romagna, Italy. J Epidemiol Community Health. 2004;58:97-102. 
36. Miyata H, Motomura N, Kondo J, Takamoto S, Hasegawa T. Improving the quality of healthcare in Japan: a systematic review of procedural volume and outcome literature. Biosci Trends. 2007;1:81-9.

37. Thompson M, Holt P, Loftus I, Forbes TL. Debate: Whether abdominal aortic aneurysm surgery should be centralized at higher-volume centers. J Vasc Surg. 2011;54:1208-14.

38. Forbes TL. Part two: The case against centralisation of abdominal aortic aneurysm surgery in higher volume centers. Eur J Vasc Endovasc Surg. 2011;42:414-7.

39. Stitzenberg KB, Sigurdson ER, Egleston BL, Starkey RB, Meropol NJ. Centralization of cancer surgery: Implications for patient access to optimal care. J Clin Oncol. 2009;27:4671-8.

40. Stitzenberg KB, Meropol NJ. Trends in centralization of cancer surgery. Ann Surg Oncol. 2010;17:2824-31.

41. Mungall IJ. Trend towards centralisation of hospital services, and its effect on access to care for rural and remote communities in the UK. Rural Remote Health. 2005;5:390.

42. Birkmeyer JD, Siewers AE, Marth NJ, Goodman DC. Regionalization of high-risk surgery and implications for patient travel times. JAMA. 2003;290:2703-8.

43. Payne $\mathrm{S}$, Jarrett N, Jeffs $\mathrm{D}$, Brown L. Implications of social isolation during cancer treatment. The implications of residence away from home during cancer treatment on patients' experiences: a comparative study. Health Place. 2001;7:273-82.

44. Federal Joint Committee (G-BA): minimum volume regulation: https:// www.g-ba.de/informationen/richtlinien/5/.

45. Federal Joint Committee (G-BA): regulations on hospital quality reports: https://www.g-ba.de/informationen/richtlinien/39/.

46. de Cruppé W, Ohmann C, Blum K, Geraedts M. Evaluating compulsory minimum volume standards in Germany: how many hospitals were compliant in 2004? BMC Health Serv Res. 2007;7:165.

47. Geraedts M, de Cruppé W, Blum K, Ohmann C. Implementation and effects of Germany's minimum volume regulations - results of the accompanying research. Dtsch Arztebl. 2008;105:890-6.

48. de Cruppé W, Ohmann C, Blum K, Geraedts M. Influence of minimum volumes on the structure of inpatient care. Gesundheitswesen. 2008;70:9-17.

49. Geraedts M, de Cruppé W, Blum K, Ohmann C. Distances to hospitals performing minimum volume relevant procedures in Germany 2004 to 2006. Gesundheitswesen. 2010;72:271-8.

50. de Cruppé W, Malik M, Geraedts M. Achieving minimum caseload requirements: an analysis of hospital quality control reports from 2004-2010. Dtsch Arztebl Int. 2014;111:549-55.

51. Simoes E, Bauer S, Schwoerer P, Schmahl FW. The structurizing effect of minimum quantitative requirements for inpatient care. Gesundheitswesen. 2005;67:96-100.

52. Roeder N, Wenke A, Heumann M, Franz D. Volume outcome relationship. Consequences of reallocation of minimum volume based on current German surgical regulations. Chirurg. 2007;78:1018-27.

53. Geraedts M, Kühnen C, de Cruppé W, Blum K, Ohmann C. Hospitals failing minimum volumes in 2004: reasons and consequences. Gesundheitswesen 2008;70:63-7.

54. Geraedts M, Malik M, Jung O, de Cruppé W. Breast cancer centres in North Rhine-Westphalia - case volume trends 2004-2010. Gesundheitswesen. 2013;75:424-9.

55. Finlayson SRG, Birkmeyer JD, Tosteson A, Nease RF. Patient preferences for location of care: implications for regionalization. Med Care. 1999;37:204-9.

\section{Submit your next manuscript to BioMed Central and take full advantage of:}

- Convenient online submission

- Thorough peer review

- No space constraints or color figure charges

- Immediate publication on acceptance

- Inclusion in PubMed, CAS, Scopus and Google Scholar

- Research which is freely available for redistribution 